\title{
Mineral Composition of Lentils: Physiological Functions, Antinutritional Effects, and Bioavailability Enhancement
}

\author{
Asmaa Benayad (iD) and Youssef Aboussaleh \\ Department of Life Sciences, Faculty of Sciences, University Ibn Tofail, B.P. 133, 14000 Kenitra, Morocco \\ Correspondence should be addressed to Asmaa Benayad; asmaa.benayad@uit.ac.ma
}

Received 8 February 2021; Accepted 15 May 2021; Published 25 May 2021

Academic Editor: Marina Carcea

Copyright (C) 2021 Asmaa Benayad and Youssef Aboussaleh. This is an open access article distributed under the Creative Commons Attribution License, which permits unrestricted use, distribution, and reproduction in any medium, provided the original work is properly cited.

Lentil (Lens culinaris) is an important nutritious crop, grown and consumed throughout the world due to its high macro- and micronutrients contents, including minerals. Minerals have several beneficial influences on human health. Thus, lentils play a major role in food security, particularly among low-income countries. The current review aims to highlight the present knowledge on the mineral composition of lentils, compare it with the recommended dietary allowance and adequate intake of minerals, investigate the literature regarding its physiological role, give detailed information on different antinutritional factors preventing its bioavailability, and present adopted solutions to enhance the bioavailability of minerals in lentil seeds. Thereby, a literature search was conducted using reliable sources: Elsevier, Springer, PubMed, and CrossRef. Based on the previous studies, $100 \mathrm{~g}$ of cooked lentils, for example, may be enough to cover the recommended dietary allowance/adequate intake of iron in infants under six months and children aged one to three years. One hundred grams of cooked lentils may also cover the recommended dietary allowance/adequate intake of zinc and magnesium in infants and children aged one to three years. Hence, it is imperative that the scientists continue to show the significance of pulses as a mineral source and their effects on human health. Indeed, lentils should be exploited for a variety of purposes, mainly towards eliminating malnutrition, on the condition of being well-balanced. Lentils should be incorporated either in snacks or while preparing household, school, or hospital meals, particularly in developing countries.

\section{Introduction}

Pulses are often recommended in sustainable diets because of their nutritional and environmental benefits [1]. Their environmental importance is linked to their ability to restore soil nitrogen without the addition of fertilizers. Hence, diversifying crop rotations with pulses is a green solution to increase system productivity [2]. The nutritional interest of pulses is related to their ability to fulfill the essential nutrients requirements of the human diet. Lentil, belonging to the Lens culinaris species and the Leguminosae family, is a small edible pulse [3]. It is one of the oldest and most appreciated food crops that has been grown in the world and originated from southwestern Asia as early as 7000 BC [4]. Legumes, including lentils, are considered as poor man's meat [5]. Indeed, whole grains, at the base of all food pyramids, are known for giving more taste and offering widely perceived health properties; they are linked to a lower risk of heart disease, diabetes, certain cancers, and other health problems [6]. In addition, many studies have described pulses, including lentils, as a potential whole food source for people suffering from micronutrients malnutrition [7]. In addition to the macronutrients, many micronutrients and phytochemicals in lentils may also be important contributors to human health [8]. In fact, lentil presents an excellent source of minerals, intervening in the insurance of food and nutritional security of millions of people, mainly in developing countries. However, this pulse is well-known for containing some natural chelating agents that can exhibit ambivalent nutritional value depending on their amount in the diet [9], such as phytic acid, trypsin inhibitors, and tannins. Phytic acid, for instance, reduces the 
bioavailability of minerals [10]. This adverse impact could be minimized by heat treatment, fermentation, and germination of lentils before ingestion [11].

Due to the lack of scientific literature reviews which, at the same time, encompass the maximum information on lentil minerals contents, the present study made a comparison with their recommended dietary allowance and adequate intake, their physiological functions, the antinutritional factors that may be involved, and the solutions allowing their bioavailability in the prepared lentil-based foods. It comprehensively aims to surround all of these aspects in a single work, based on the precedent researches.

\section{Methodology}

This review included, in a first step, the selection of the topic to be addressed. For this, a previous search was conducted on the literature to evaluate whether such a review had already been undertaken, which demonstrated that this was a field in which it would be appropriate to gather in a review paper the information available scattered around the scientific literature. After establishing the study subjects, a search was carried out using reliable scientific database such as Elsevier, Springer, PubMed, and CrossRef. The articles were selected, based on the objectives of the review, by examining their titles, abstracts, and reference list and focusing on the publication date being as recent as possible. Then, after selecting suitable keywords, the review was structured into different sections as follows [12-14]:

(1) A brief introduction for contextualization

(2) The methodology section explaining the followed steps

(3) The body of the review, which is structured into sections as follows:

(3.1) General facts about lentils

(3.2) Recommended dietary allowance and adequate intake in minerals

(3.3) Mineral composition of raw, dehulled, and cooked lentils seeds, divided into the following:

(3.3.1) Physiological functions of lentils minerals

(3.3.2) Antinutritional factors (mineral chelating agents)

(3.3.3) Bioavailability enhancement of minerals in lentils

(3.4) Storage of food legumes

(3.5) Consumption of lentil seeds

\section{(4) Conclusion}

Figure 1 shows a sector which highlights the number of the adopted documents by the journal's title (journal occurrence) for the used sources in the review; the most frequent journals were Nutrients, Trends in Food Science \& Technology, and Food Chemistry. They were followed by Journal of Food Composition and Analysis, LWT-Food Science and Technology, and British Journal of Nutrition.

\section{Current Status of Knowledge}

3.1. General Facts about Lentils. Lentils have different names depending on the countries. The most common names are lentil (English), Adas (Arabic), Mercimek (Turkish), Messer (Ethiopia), Heramame (Japanese) [15], and Daal or Dahl (Hindi). The taxonomic classification of lentils is shown in Figure 2 [16]. Lentils are growing worldwide and their production has markedly increased over the last few decades [17]. According to FAO (2019) statistics (Table 1), average annual global production of lentil was reported to be 5734201 tons; Canada, India, and USA are the major lentilproducing countries [18].

3.2. Recommended Dietary Allowance and Adequate Intake of Minerals. The recommended dietary allowance (RDA) is defined as the average daily dietary intake level that is enough to meet the nutrient requirements of nearly all (97\%-98\%) healthy persons of a determined age, sex, life stage, or physiological state (pregnancy or lactation). By definition, the RDA exceeds the actual needs of all but about $2 \%-3 \%$ of the population. Thus, many individuals who are under the RDA may still be getting sufficient amounts of the nutrient in question to be above their requirement level [19]. According to the Institute of Medicine (US), setting the RDA requires the determination of the estimated average requirement (EAR), defined as the daily intake value of a nutrient that is estimated to meet the nutrient needs of half the healthy individuals in a gender group and life stage. Moreover, setting the EAR requires the selection of a specific criterion of adequacy, based on a good review of the literature. When selecting the criterion, reduction of disease risk is taken into account with other health parameters. The RDA is set at the EAR plus twice the standard deviation (SD) if available as follows: $\mathrm{RDA}=\mathrm{EAR}+2 \mathrm{SD}$. If data about variability in requirements are insufficient to calculate an $\mathrm{SD}$, a coefficient of variation for the EAR of $10 \%$ is supposed $(\mathrm{RDA}=1.2 \times \mathrm{EAR})$. Setting $\mathrm{RDA}$ is not possible for some nutrients, because data on the requirement EAR for the function of health significance that are considered being the most important are not available. Thus, to make helpful statements about healthful nutrient intake levels, adequate intake (AI) is set instead of an RDA; it is based on observed or experimentally determined estimates of nutrient intake by a group(s) of healthy people [20]. The RDA and the AI in Fe [21], Zn [22], copper [23], manganese [24], calcium $[25,26], \mathrm{K}[27], \mathrm{Na}[28], \mathrm{P}$ [29], $\mathrm{Mg}$ [30], and Se [31] are presented in Table 2.

3.3. Mineral Composition of Raw, Dehulled, and Cooked Lentil Seeds. Lentil grain is a plentiful source of minerals. Mineral content of raw, dehulled, and cooked lentils was determined in many previous studies that were carried out in different countries including USA [32], Egypt [33], Pakistan [34], and Canada $[35,36]$ as presented in Table 3. Generally, the traditional preparation of lentil requires two steps: soaking $(18 \mathrm{~h}$ to $24 \mathrm{~h})$ and cooking $\left(15 \mathrm{~min}\right.$ to $2 \mathrm{~h}$ at $\left.85-95^{\circ} \mathrm{C}\right)$. 


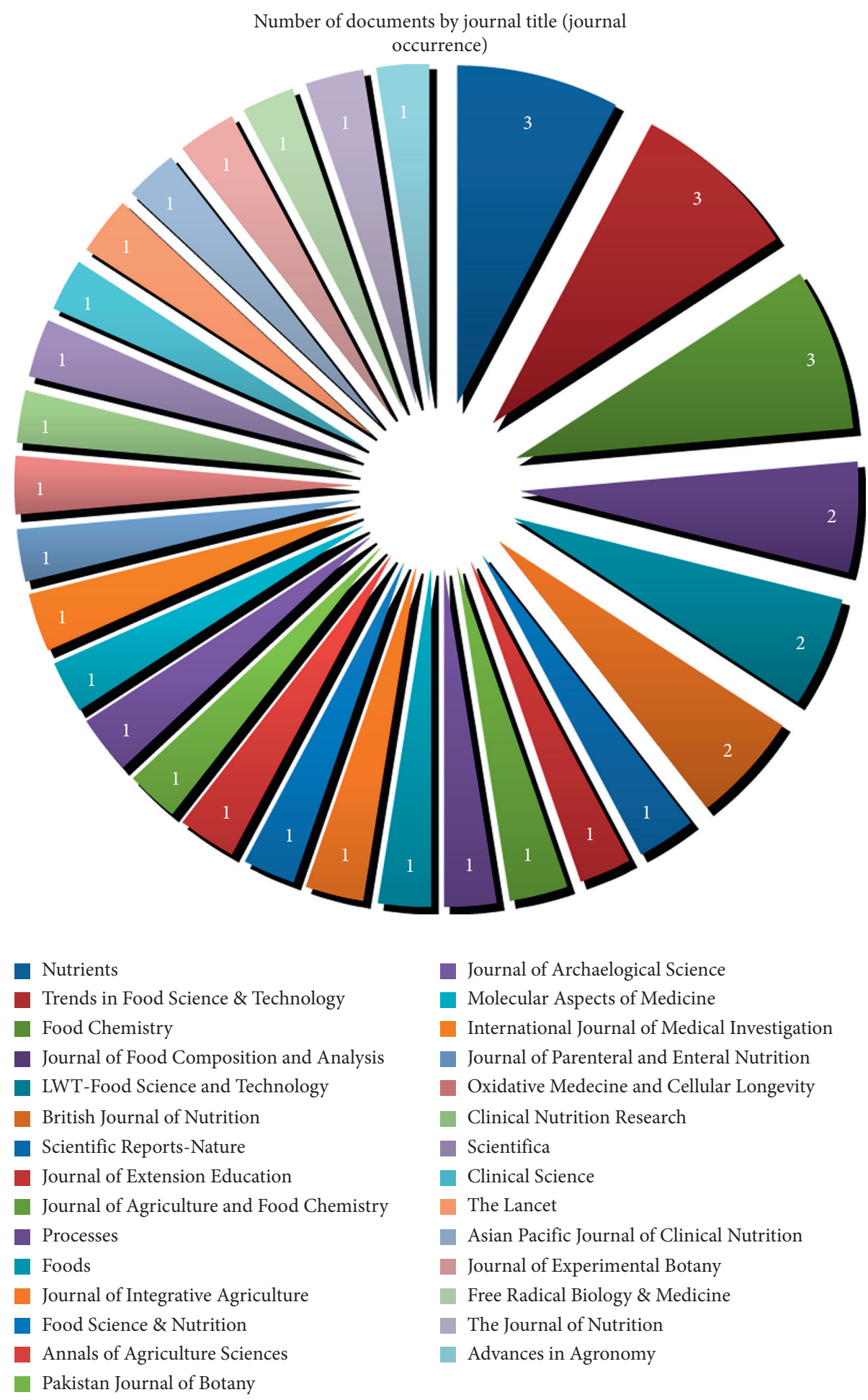

FIgURE 1: Number of documents by journal's title.

3.3.1. Physiological Functions of Lentil Minerals. Notwithstanding that pulses have been consumed for thousands of years for their nutritional features [37], it is only during the past decades that interest in their potential effects on human health has been revived [38]. Pulse minerals, including those of lentils, play physiological roles in the body.
Iron (Fe) is vital for almost all living organisms; it is involved in a wide variety of metabolic processes, including oxygen transport, DNA synthesis, and electron transport [39]. Zinc $(\mathrm{Zn})$ is an important element for humans and is extensively implicated in protein, lipid, nucleic acid metabolism, and gene transcription. Its function within the human body is extensive in reproduction, wound repair, 


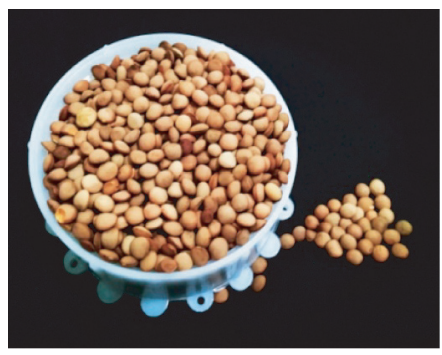

Kingdom: Plantae Subkingdom: Angiosperm Division: Eudicots Subclass: Rosids Order: Fabales Family: Fabaceae Subfamily: Faboideae Tribe: Vicieae Genus: Lens Species: culinaris

Figure 2: A photo (in the left side) and taxonomic description (in the right side) of lentils.

TABLE 1: Global lentil production in 2019 (tons/years).

\begin{tabular}{|c|c|}
\hline Country & Value \\
\hline Algeria & 26524 \\
\hline Argentina & 16299 \\
\hline Armenia & 127 \\
\hline Australia & 533755 \\
\hline Azerbaijan & 1039 \\
\hline Bangladesh & 175384 \\
\hline Argentina & 16299 \\
\hline Canada & 2166900 \\
\hline Chile & 1400 \\
\hline China & 164239 \\
\hline Colombia & 1653 \\
\hline Egypt & 1087 \\
\hline Ecuador & 3046 \\
\hline Eritrea & 151 \\
\hline United States of America & 244400 \\
\hline Ethiopia & 119329 \\
\hline Russian Federation & 116618 \\
\hline India & 1227820 \\
\hline Iran & 70662 \\
\hline Iraq & 10 \\
\hline Israel & 25 \\
\hline Jordan & 153 \\
\hline Kazakhstan & 75386 \\
\hline Kenya & 1616 \\
\hline Lebanon & 1578 \\
\hline Libya & - \\
\hline Madagascar & 831 \\
\hline Malawi & 789 \\
\hline Morocco & 37095 \\
\hline Mexico & 9469 \\
\hline Myanmar & 732 \\
\hline Nepal & 251185 \\
\hline New Zealand & 2087 \\
\hline Uzbekistan & 887 \\
\hline Pakistan & 5957 \\
\hline Peru & 2936 \\
\hline Syrian Arab Republic & 100653 \\
\hline Tajikistan & 1011 \\
\hline Palestine & 1361 \\
\hline Tunisia & 1123 \\
\hline Turkey & 353631 \\
\hline Ukraine & 8040 \\
\hline Yemen & 7115 \\
\hline
\end{tabular}

immune function, and, on the microcellular level, macrophage, neutrophil, natural killer cell, and complement activity [40]. Copper $(\mathrm{Cu})$ is an essential catalyst for heme synthesis and Fe absorption; it is in its many form the third most common mineral in the body [41]. It is a necessary element essential for the neurologic and haematologic system [42]. Manganese (Mn) is an important component that is implicated in the synthesis and activation of several enzymes and in the regulation of the metabolism of glucose and lipids in humans [43]. Calcium (Ca) is an important nutrient that is necessary for several functions in human health; it is the most prevalent mineral in the body with $99 \%$ found in bone and teeth. Ca metabolism includes other nutrients such as protein, vitamin D, and P [44]. Potassium $(\mathrm{K})$ is an essential nutrient; it is the most abundant cation in intracellular fluid, where it plays an important role in maintaining cell function. Its gradient across the cell membrane determines cellular membrane potential, which is maintained in large part by the ubiquitous ion channel the $\mathrm{Na}-\mathrm{K}(\mathrm{Na}+-\mathrm{K}+)$ ATPase pump [45]. Magnesium $(\mathrm{Mg})$ is an essential constituent needed as a cofactor for over 300 enzymatic reactions and is thus important for the biochemical functioning of many metabolic pathways [46]. $\mathrm{Mg}$ is necessary for regulation of muscle contraction (including that of the heart), blood pressure, and insulin metabolism and is needed for the synthesis of DNA, RNA, and proteins [47]. Phosphorus (P) is an important element needed for vital biological reactions that maintain the normal homoeostatic control of the cell. This nutrient is an essential component of many cellular structures, including nucleic acids and cell membranes. Adequate $\mathrm{P}$ balance is critical for maintaining basic cellular functions, ranging from energy metabolism to cell signaling. Furthermore, many intracellular pathways utilize phosphate ions for essential cellular reactions; therefore, homoeostatic control of phosphate is considered as one of the most precise biological regulations [48]. Sodium $(\mathrm{Na})$ is an essential mineral for human health to maintain plasma volume, regulating body water content and electrolyte balance, transmission of nerve impulses, and normal cell function; however, its excess in human diet leads to high blood pressure. This problem is often correlated with high consumption of sugar and fat, besides salt [49]. Selenium (Se) is an essential trace mineral of fundamental importance to human health. As a component of selenoproteins, Se has enzymic and structural functions, and it is best known as an antioxidant and catalyst for the production of active thyroid hormone. Se is required for the proper functioning of the immune system and seems to be a key nutrient in counteracting the development of virulence and inhibiting HIV progression to AIDS [50].

\subsubsection{Antinutritional Factors (Mineral Chelating Agents).} Although lentils are rich in minerals, their bioavailability is limited due to the existence of multiple antinutritive factors, such as phytates, phenolic compounds, and oxalic acid. This can lead to many health problems, among which is anemia. According to [51], negative correlations were found between mineral chelating agents and nutrients bioavailability and digestibility. According to [52], all major types of food polyphenols are strongly able to inhibit dietary non-haem Fe absorption. Oxalates in food strongly chelate with dietary 
TABLE 2: Recommended dietary allowance and adequate intake in minerals according to the Institute of Medicine.

\begin{tabular}{|c|c|c|c|c|c|c|c|c|c|c|c|}
\hline \multirow{2}{*}{\multicolumn{2}{|c|}{ Life stage }} & \multicolumn{10}{|c|}{ RDA/AI* } \\
\hline & & \multirow{3}{*}{$\begin{array}{c}\mathrm{Fe}(\mathrm{mg} / \mathrm{d}) \\
0.27^{*} \\
11\end{array}$} & \multirow{3}{*}{$\begin{array}{c}\mathrm{Zn}(\mathrm{mg} / \mathrm{d}) \\
2^{*} \\
3\end{array}$} & \multirow{3}{*}{$\begin{array}{c}\mathrm{Cu}(\mu \mathrm{g} / \mathrm{d}) \\
200^{*} \\
220^{*}\end{array}$} & \multirow{3}{*}{$\begin{array}{c}\mathrm{Mn}(\mathrm{mg} / \mathrm{d}) \\
0.003^{*} \\
0.6^{*}\end{array}$} & \multirow{3}{*}{$\begin{array}{c}\mathrm{Ca}(\mathrm{mg} / \mathrm{d}) \\
200^{*} \\
260^{*}\end{array}$} & \multirow{3}{*}{$\begin{array}{c}\mathrm{K}(\mathrm{g} / \mathrm{d}) \\
0.4^{*} \\
0.7^{*} \\
\end{array}$} & \multirow{3}{*}{$\begin{array}{c}\mathrm{Mg}(\mathrm{mg} / \mathrm{d}) \\
30^{*} \\
75^{*} \\
\end{array}$} & \multirow{3}{*}{$\begin{array}{c}\mathrm{P}(\mathrm{mg} / \mathrm{d}) \\
100^{*} \\
275^{*}\end{array}$} & \multirow{3}{*}{$\begin{array}{c}\mathrm{Na}(\mathrm{g} / \mathrm{d}) \\
0.12^{*} \\
0.37^{*} \\
\end{array}$} & \multirow{3}{*}{$\begin{array}{c}\text { Se }(\mu \mathrm{g} / \mathrm{d}) \\
15^{*} \\
20^{*}\end{array}$} \\
\hline & $0-6 \mathrm{mo}$ & & & & & & & & & & \\
\hline Infants & $6-12 \mathrm{mo}$ & & & & & & & & & & \\
\hline \multirow{2}{*}{ Children } & $1-3 y$ & 7 & 3 & 340 & $1.2^{*}$ & 700 & $3.0^{*}$ & 80 & 460 & $1.0^{*}$ & 20 \\
\hline & $4-8 y$ & 10 & 5 & 440 & $1.5^{*}$ & 1000 & $3.8^{*}$ & 130 & 500 & $1.2^{*}$ & 30 \\
\hline \multirow{6}{*}{ Females } & $9-13 y$ & 8 & 8 & 700 & $1.6^{*}$ & 1300 & $4.5^{*}$ & 240 & 1250 & $1.5^{*}$ & 40 \\
\hline & $14-18 \mathrm{y}$ & 15 & 9 & 890 & $1.6^{*}$ & 1300 & $4.7^{*}$ & 360 & 1250 & $1.5^{*}$ & 55 \\
\hline & $19-30 y$ & 18 & 8 & 900 & $1.8^{*}$ & 1000 & $4.7^{*}$ & 310 & 700 & $1.5^{*}$ & 55 \\
\hline & $31-50 y$ & 18 & 8 & 900 & $1.8^{*}$ & 1000 & $4.7^{*}$ & 320 & 700 & $1.5^{*}$ & 55 \\
\hline & $51-70$ & 8 & 8 & 900 & $1.8^{*}$ & 120 & $4.7^{*}$ & 320 & 700 & $1.3^{*}$ & 55 \\
\hline & $>70 y$ & 8 & 8 & 900 & $1.8^{*}$ & 1200 & $4.7^{*}$ & 320 & 700 & $1.2^{*}$ & 55 \\
\hline \multirow{6}{*}{ Males } & $9-13 y$ & 8 & 8 & 700 & $1.9^{*}$ & 1300 & $4.5^{*}$ & 240 & 1250 & $1.5^{*}$ & 40 \\
\hline & $14-18 y$ & 11 & 11 & 890 & $2.2^{*}$ & 1300 & $4.7^{*}$ & 410 & 1250 & $1.5^{*}$ & 55 \\
\hline & $19-30 y$ & 8 & 11 & 900 & $2.3^{*}$ & 1000 & $4.7^{*}$ & 400 & 700 & $1.5^{*}$ & 55 \\
\hline & $31-50 y$ & 8 & 11 & 900 & $2.3^{*}$ & 1000 & $4.7^{*}$ & 420 & 700 & $1.5^{*}$ & 55 \\
\hline & $51-70$ & 8 & 11 & 900 & $2.3^{*}$ & 1000 & $4.7^{*}$ & 420 & 700 & $1.3^{*}$ & 55 \\
\hline & $>70 y$ & 8 & 11 & 900 & $2.3^{*}$ & 1200 & $4.7^{*}$ & 420 & 700 & $1.2^{*}$ & 55 \\
\hline \multirow{3}{*}{ Pregnancy } & $14-18 y$ & 27 & 12 & 1000 & $2.0^{*}$ & 1300 & $4.7^{*}$ & 400 & 1250 & $1.5^{*}$ & 60 \\
\hline & $19-30 y$ & 27 & 11 & 1000 & $2.0^{*}$ & 1000 & $4.7^{*}$ & 350 & 700 & $1.5^{*}$ & 60 \\
\hline & $31-50 y$ & 27 & 11 & 1000 & $2.0^{*}$ & 1000 & $4.7^{*}$ & 360 & 700 & $1.5^{*}$ & 60 \\
\hline \multirow{3}{*}{ Lactation } & $14-18 y$ & 10 & 13 & 1300 & $2.6^{*}$ & 1300 & $5.1^{*}$ & 360 & 1250 & $1.5^{*}$ & 70 \\
\hline & $19-30 y$ & 9 & 12 & 1300 & $2.6^{*}$ & 1000 & $5.1^{*}$ & 310 & 700 & $1.5^{*}$ & 70 \\
\hline & $31-50 y$ & 9 & 12 & 1300 & $2.6^{*}$ & 1000 & $5.1^{*}$ & 320 & 700 & $1.5^{*}$ & 70 \\
\hline
\end{tabular}

RDA: recommended dietary allowance (RDA); AI: adequate intake; IOM: Institute of Medicine; DRI: dietary reference intake. The table is adopted from DRI reports accessed via www.nap.edu, according to IOM. It represents RDAs in bold type and $\mathrm{AI}$ in ordinary type followed by an asterisk ( $\left.{ }^{*}\right)$ for Fe, $\mathrm{Zn}, \mathrm{Cu}, \mathrm{Ca}$, $\mathrm{Mg}, \mathrm{K}, \mathrm{Na}$, and $\mathrm{P}$.

TABle 3: Mineral lentil composition (unit: $\mathrm{mg} / 100 \mathrm{~g}$ ).

\begin{tabular}{|c|c|c|c|c|c|c|c|c|c|c|c|c|c|}
\hline Countries & Tyl & & $\mathrm{Fe}$ & $\mathrm{Zn}$ & $\mathrm{Cu}$ & $\mathrm{Mn}$ & $\mathrm{Ca}$ & $\mathrm{K}$ & $\mathrm{Mg}$ & $\mathrm{P}$ & $\mathrm{Na}$ & Se $(\mu / \mathrm{kg})$ & References \\
\hline \multirow{16}{*}{ USA } & \multirow{7}{*}{ Green variety } & Raw (2018) & 5.3 & 3.3 & 0.8 & 1.5 & 49.1 & 771.4 & 103.3 & 524.9 & - & 226.0 & \multirow{16}{*}{ [33] } \\
\hline & & Raw (2017) & 6.3 & 3.7 & 0.9 & 1.4 & 49.3 & 705.7 & 104.8 & 263.2 & - & 236.0 & \\
\hline & & Raw (2016) & 6.2 & 2.5 & 0.6 & 1.2 & 53.4 & 540.1 & 102.6 & 389.0 & - & 179.0 & \\
\hline & & Raw (2015) & 8.0 & 2.7 & 0.7 & 1.3 & 44.9 & 6111.1 & 114.9 & 269.5 & - & 279.0 & \\
\hline & & Raw (2014) & 6.1 & 4.0 & 0.7 & 1.7 & 76.1 & 849.3 & 78.9 & 257.4 & - & 369.0 & \\
\hline & & Raw (2013) & 5.7 & 3.5 & 0.7 & 1.5 & 49.6 & 693.6 & 59.7 & 293.1 & - & 727.0 & \\
\hline & & Raw (2012) & 6.9 & 3.4 & - & - & 29.3 & 695.4 & 36.7 & - & - & 726.0 & \\
\hline & \multirow{9}{*}{ Red variety } & Raw (2011) & 5.3 & 2.9 & - & - & 50.1 & 625.5 & 76.1 & - & - & 456.0 & \\
\hline & & Raw (2018) & 4.8 & 4.1 & 0.9 & 1.8 & 47.6 & 831.3 & 103.0 & 583.4 & - & 193.0 & \\
\hline & & Raw (2017) & 7.4 & 3.8 & 0.9 & 1.5 & 53.0 & 680.8 & 101.6 & 290.6 & - & 223.0 & \\
\hline & & Raw (2016) & 6.4 & 2.7 & 0.7 & 1.5 & 57.3 & 563.7 & 103.5 & 356.9 & - & 189.0 & \\
\hline & & Raw (2015) & 12.3 & 2.9 & 0.7 & 1.5 & 59.0 & 596.2 & 114.5 & 269.5 & - & 269.0 & \\
\hline & & Raw (2014) & 6.2 & 4.1 & 0.7 & 1.3 & 64.7 & 841.6 & 77.2 & 296.0 & - & 397.0 & \\
\hline & & Raw (2013) & 7.5 & 4.5 & 0.7 & 2.0 & 46.0 & 776.1 & 67.7 & 390.9 & - & 379.0 & \\
\hline & & Raw (2012) & 7.9 & 4.0 & - & - & 41.8 & 724.3 & 48.2 & - & - & 503.0 & \\
\hline & & Raw (2011) & 6.7 & 3.3 & - & - & 56.9 & 610.8 & 72.0 & - & - & 347.0 & \\
\hline \multirow{2}{*}{ Egypt } & \multirow{2}{*}{\multicolumn{2}{|c|}{$\begin{array}{l}\text { Raw } \\
\text { Boiled }\end{array}$}} & 7.3 & 4.3 & 1.0 & 2.4 & 97.3 & 960.0 & 138.0 & 541.0 & 78.0 & - & \multirow{2}{*}[34]{} \\
\hline & & & 6.1 & 3.4 & 0.7 & 1.8 & 50.2 & 420.0 & 118.0 & 462.0 & 72.0 & - & \\
\hline \multirow{2}{*}{ Pakistan } & \multirow{2}{*}{\multicolumn{2}{|c|}{$\begin{array}{c}\text { Raw } \\
\text { Boiled }\end{array}$}} & 3.1 & 4.4 & 9.9 & - & 120.0 & 874.0 & 1.6 & 294.0 & 79.0 & - & \multirow{2}{*}[35]{} \\
\hline & & & - & - & - & - & - & - & - & - & - & - & \\
\hline
\end{tabular}


TABle 3: Continued.

\begin{tabular}{|c|c|c|c|c|c|c|c|c|c|c|c|c|c|}
\hline Countries & & & $\mathrm{Fe}$ & $\mathrm{Zn}$ & $\mathrm{Cu}$ & $\mathrm{Mn}$ & $\mathrm{Ca}$ & $\mathrm{K}$ & $\mathrm{Mg}$ & $\mathrm{P}$ & $\mathrm{Na}$ & Se $(\mu / \mathrm{kg})$ & References \\
\hline \multirow{24}{*}{ Canada } & \multirow{3}{*}{ Variety 1} & Raw & 9.18 & 3.64 & 1.13 & 1.32 & 68.7 & 943.0 & 109.0 & 394.0 & - & - & \multirow{24}{*}[36]{} \\
\hline & & Cooked & 7.11 & 3.44 & 0.86 & 1.42 & 67.4 & 567.0 & 103.5 & 365.5 & - & - & \\
\hline & & Dehulled & 5.93 & 3.53 & 0.83 & 1.04 & 25.5 & 1008.5 & 83.5 & 415.3 & - & - & \\
\hline & \multirow{3}{*}{ Variety 2} & Raw & 7.22 & 3.16 & 0.79 & 1.36 & 60.7 & 851.0 & 105.0 & 374.8 & - & - & \\
\hline & & Cooked & 6.16 & 2.94 & 0.86 & 1.47 & 67.4 & 538.0 & 100.1 & 329.3 & - & - & \\
\hline & & Dehulled & 5.9 & 3.12 & 0.72 & 1.19 & 24.9 & 943.5 & 90.5 & 395.5 & - & - & \\
\hline & \multirow{3}{*}{ Variety 3} & Raw & 7.58 & 3.12 & 0.89 & 1.35 & 76.2 & 885.0 & 108.5 & 364.3 & - & - & \\
\hline & & Cooked & 5.93 & 2.75 & 1.04 & 1.41 & 79.6 & 512.0 & 94.5 & 309.5 & - & - & \\
\hline & & Dehulled & 5.86 & 2.99 & 0.78 & 1.25 & 28.1 & 951.0 & 89.7 & 388.8 & - & - & \\
\hline & \multirow{4}{*}{ Variety 4} & Raw & 8.05 & 2.82 & 0.84 & 1.5 & 71.3 & 861.5 & 108.5 & 360.5 & - & - & \\
\hline & & Cooked & 6.9 & 2.57 & 0.91 & 1.57 & 75.3 & 531.5 & 96.3 & 312.5 & - & - & \\
\hline & & Dehulled & 6.17 & 2.78 & 0.7 & 1.31 & 28.6 & 914 & 96.3 & 389.5 & - & - & \\
\hline & & Raw & 6.41 & 2.63 & 1.0 & 1.05 & 57.5 & 848.5 & 102.8 & 407.0 & - & - & \\
\hline & \multirow[t]{3}{*}{ Variety 5} & Cooked & 5.79 & 2.41 & 1.11 & 1.11 & 61.5 & 542.0 & 90.7 & 361.5 & - & - & \\
\hline & & Dehulled & 5.95 & 2.6 & 0.73 & 0.95 & 20.0 & 894.0 & 76.2 & 438.5 & - & - & \\
\hline & & Raw & 6.25 & 2.74 & 0.97 & 1.0 & 69.4 & 843.5 & 99.3 & 308.0 & - & - & \\
\hline & \multirow[t]{3}{*}{ Variety 6} & Cooked & 5.84 & 2.39 & 1.09 & 1.06 & 77.6 & 456.5 & 79.5 & 283.5 & - & - & \\
\hline & & Dehulled & 5.9 & 2.7 & 0.75 & 0.94 & 24.2 & 885.0 & 71.7 & 335.5 & - & - & \\
\hline & & Raw & 7.61 & 2.98 & 0.96 & 1.41 & 62.3 & 880.5 & 109.0 & 402.0 & - & - & \\
\hline & \multirow[t]{3}{*}{ Variety 7} & Cooked & 7.04 & 2.76 & 1.14 & 1.48 & 70.2 & 603.5 & 99.8 & 380.0 & - & - & \\
\hline & & Dehulled & 7.10 & 2.88 & 0.9 & 1.29 & 21.9 & 946.5 & 84.5 & 432.0 & - & - & \\
\hline & & Raw & 7.92 & 3.79 & 1.02 & 1.28 & 59.2 & 896.5 & 105.0 & 385.8 & - & - & \\
\hline & \multirow[t]{2}{*}{ Variety 8} & Cooked & 7.29 & 3.53 & 1.17 & 1.35 & 63.4 & 643.0 & 95.2 & 360.0 & - & - & \\
\hline & & Dehulled & 6.72 & 3.71 & 0.89 & 1.1 & 23.0 & 939.5 & 81.2 & 418.0 & - & - & \\
\hline \multirow{4}{*}{ Canada } & Variety 1 & Raw & 7.3 & 4.3 & 1.0 & 2.4 & 97.3 & 1134.6 & 138.8 & 541.6 & - & - & \multirow{4}{*}{ [37] } \\
\hline & Variety 2 & Raw & 8.5 & 3.3 & 0.8 & 1.5 & 76.4 & 992.4 & 130.7 & 462.0 & - & - & \\
\hline & Variety 3 & Raw & 8.0 & 4.4 & 1.2 & 1.7 & 64.0 & 976.4 & 136.1 & 465.5 & - & - & \\
\hline & Variety 4 & Raw & 7.7 & 4.3 & 1 & 1.9 & 81.3 & 1116.9 & 147.1 & 568.4 & - & - & \\
\hline
\end{tabular}

All samples are on dry weight basis.

minerals such as calcium to form complexes and precipitate as insoluble salts accumulating in the renal glomeruli and lead to the development of renal problems, such as kidney stone formation [53]. In fact, while these antinutrients negatively affect nutrient absorption, they are also considered to play a beneficial role in preventing coronary heart disease and cancer [54]. Phytic acid (myo-inositol-1, 2, 3, 4, 5,6 , hexabisphosphates, IP6) is an ubiquitous component that represents $1 \%$ to $5 \%$ by weight of most pulses [55], and it is the main source of phosphorous in their seeds [56]. In adults, phytic acid inhibits the absorption of $\mathrm{Fe}, \mathrm{Zn}, \mathrm{Ca}$, and $\mathrm{Mn}$, but not $\mathrm{Cu}$. It is a strong inhibitor of Fe absorption in both infants and adults, but its impact on $\mathrm{Zn}$ absorption in infants sounds to be modest and maybe most significant in children recovering from infection. Phytic acid slightly influences $\mathrm{Ca}$ and $\mathrm{Mg}$ absorption. In fact, Fe and $\mathrm{Zn}$ deficiencies are common in infants and young children, especially in developing countries; thus, their bioavailability from complementary food is a major concern [57]. Phytic acid concentration in lentil seeds depends to genotypic variation, climatic conditions, soil nature, and other unexplained factors [7].

3.3.3. Bioavailability Enhancement of Minerals in Lentils. Different methods have been developed to decrease the phytic acid content in food and improve its nutritional quality, which becomes poor due to such antinutrients factors. These include genetic improvement and several pretreatment methods, such as soaking, fermentation, germination, and enzymatic treatment of grains with phytase enzyme [58]. Germination combined with dehulling process also improves the legumes quality by increasing the bioavailability and digestibility of nutrients and decreasing the amounts of the antinutrients [51]. The method of processing, such as cooking, results in significant decrease in tannins and phytic acid in pulses [59]. In addition, food preparation methods and other dish components [60] also influence the phytic acid concentration and other antinutritional factors.

3.4. Storage of Food Legumes. Food legumes storage is done at all steps from farmer to trader in different types of storage units until the next season's yield. Farmers generally keep a part of their harvest for family utilization and animal feed. In developing countries, legumes are stored at the trader and government levels as insurance against future crops of low harvest or poor quality and against change in market demand and price. Compared with other crops, losses of legume seeds due to storage are quite high. These losses are due to many physical, biological, and engineering factors; physical factors, such as moisture, temperature, and oxygen concentration; biological factors, such as insects, birds, and microorganisms; engineering factors, such as process-handling equipment and utilized storage structures [23]. 
3.5. Consumption of Lentil Seeds. Soaking legumes for up to $24 \mathrm{~h}$ in water is generally the first step to prepare the seeds for consumption. Sometimes, sprouts are formed due to food legumes germination. This leads to the improvement of flavor and nutritional quality of the seeds through the breakdown of antinutrients factors. However, soaking for long periods of time has an impact on nutritional value of legumes. Fermentation is another method of food processing; it plays a very significant function in the diet in many regions of the world. Fermented legume products are rapidly gaining popularity due to their organoleptic properties and texture. In fact, fermentation of legumes allows the elimination of undesirable flavor, prolongation of shelf-life, and improvement of digestibility and safety of the food. Another legume process traditionally utilized in Asia and Africa is milling. First, the legume seeds are often pretreated adopting dry and wet methods to help outer part (hull) removal. Both methods cause shrinkage of the endosperm, hence loosening the coat for easy removal by milling. The wet method is done by mixing legume seeds with some water, followed by draining and sun drying. The dry method, generally used in India, involves sun-drying the legume seeds after treatment with oil and a very small amount of water [23].

\section{Conclusion}

A crucial challenge today is to make our food habits healthier and more sustainable. Thus, utilizing pulse-based products, including lentils, is much recommended over the world. The nutritional importance of lentils is unquestionable due to the massive existence of minerals, polyphenols, and other required components, whose consumption plays a significant role in human health. Based on the previously recommended, $100 \mathrm{~g}$ of cooked lentils, for example, may be enough to cover the RDA/AI of Fe in infants under six months and children aged one to three years old. One hundred grams of cooked lentils may also cover the RDA/AI of $\mathrm{Zn}$ and $\mathrm{Mg}$ in infants and children aged one to three years old. Hence, it is imperative that the scientists continue to show the significance of pulses as a mineral source and their effects on human health. Indeed, lentils should be exploited for a variety of purposes, mainly towards eliminating malnutrition, on the condition of being well-balanced. Lentils should be incorporated either in snacks or while preparing household, school, or hospital meals, particularly in developing countries.

\section{Conflicts of Interest}

The authors declare that they have no conflicts of interest.

\section{References}

[1] A. Chaudhary, C. Marinangeli, D. Tremorin, and A. Mathys, "Nutritional combined greenhouse gas life cycle analysis for incorporating Canadian yellow pea into cereal-based food products," Nutrients, vol. 10, no. 4, p. 490, 2018.
[2] Y. Gan, C. Hamel, J. T. O’Donovan et al., "Diversifying crop rotations with pulses enfances system productivity," Scientific Reports, vol. 5, no. 1, p. 4625, 2015.

[3] A. Samaranayaka, "Lentil," in Sustainable Protein Sources, L. S. R. Nadathur, J. P. D. Wanasundara, and L. Scanlin, Eds., Elsevier, Amsterdam, Netherlands, pp. 185-196, 2017.

[4] P. Dhuppar, S. Biyan, B. Chintapalli, and S. Rao, "Lentil crop production in the context of climate change: an appraisal," Indian Research Journal, vol. 2, pp. 33-35, 2012.

[5] R. N. Tharanathan and S. Mahadevamma, "Grain legumes-a boon to human nutrition," Trends in Food Science \& Technology, vol. 14, no. 12, pp. 507-518, 2003.

[6] K. F. Tiefenbacher, "New products require new thinking-ideas and examples," in The Technology of Wafers and Waffles II, pp. 131-220, Elsevier, Amsterdam, Netherlands, 2019.

[7] P. Thavarajah, D. Thavarajah, and A. Vandenberg, "Low phytic acid lentils (Lens culinaris L.): a potential solution for increased micronutrient bioavailability," Journal of Agricultural and Food Chemistry, vol. 57, no. 19, pp. 9044-9049, 2009.

[8] B. Zhang, Z. Deng, Y. Tang et al., "Fatty acid, carotenoid and tocopherol compositions of 20 Canadian lentil cultivars and synergistic contribution to antioxidant activities," Food Chemistry, vol. 161, pp. 296-304, 2014.

[9] M. Margier, S. Georgé, N. Hafnaoui et al., "Nutritional composition and bioactive content of legumes: characterization of pulses frequently consumed in France and effect of the cooking method," Nutrients, vol. 10, no. 11, p. 1668, 2018.

[10] N. R. Reddy, M. D. Pierson, S. K. Sathe, and D. K. Salunkhe, "Chemical, nutritional and physiological aspects of dry bean carbohydrates-a review," Food Chemistry, vol. 13, no. 1, pp. 25-68, 1984.

[11] M. Umeta, C. E. West, and H. Fufa, "Content of zinc, iron, calcium and their absorption inhibitors in foods commonly consumed in Ethiopia," Journal of Food Composition and Analysis, vol. 18, no. 8, pp. 803-817, 2005.

[12] R. P. F. Guiné, M. J. Barroca, T. E. Coldea, E. Bartkiene, and O. Anjos, "Apple fermented products: an overview of technology, properties and health effects," Processes, vol. 9, no. 2, p. 223, 2021.

[13] R. P. F. Guiné, S. G. Florença, M. J. Barroca, and O. Anjos, "The duality of innovation and food development versus purely traditional foods," Trends in Food Science \& Technology, vol. 109, no. 1, pp. 16-24, 2021.

[14] R. P. F. Guiné, S. G. Florença, M. J. Barroca, and O. Anjos, "The link between the consumer and the innovations in food product development," Foods, vol. 9, no. 9, p. 1317, 2020.

[15] F. J. Muehlbauer and A. Tullu, Lens Culinaris Medik, Purdue University, West Lafayette, IN, USA, 1997, https://hort. purdue.edu/newcrop/CropFactSheets/lentil.html\#Common $\% 20$ Names.

[16] M. Joshi, Y. Timilsena, and B. Adhikari, "Global production, processing and utilization of lentil: a review," Journal of Integrative Agriculture, vol. 16, no. 12, pp. 2898-2913, 2017.

[17] Food and Agriculture Organization of the United Nations, FAOSTAT Database Agricultural Production, Food and Agriculture Organization of the United Nations, Rome, Italy, 2010, http://www.fao.org/faostat/en/?\#data.

[18] FAOSTAT (archive), 2019, http://www.fao.org.

[19] J. Dwyer, "Dietary requirements of adults," in Encyclopedia of Food Sciences and Nutrition (Second Edition), Academic Press, Cambridge, MA, USA, pp. 1863-1868, 2003.

[20] Institute of Medicine (US) Food and Nutrition Board, EBook of Dietary Reference Intakes: A Risk Assessment Model for 
Establishing Upper Intake Levels for Nutrients. 1998, National Academies Press (US), Washington, DC, USAhttps://www. ncbi.nlm.nih.gov/books/NBK45182/.

[21] Institute of Medicine, EBook of Dietary Reference Intakes for Vitamin A, Vitamin K, Arsenic, Boron, Chromium, Copper, Iodine, Fe, Manganese, Molybdenum, Nickel, Silicon, Vanadium, and $\mathrm{Zn}(\mathrm{Fe})$, National Academies Press (US), Washington, DC, USA, 2001, https://www.ncbi.nlm.nih.gov/books/ NBK222309/.

[22] Institute of Medicine, EBook of Dietary Reference Intakes for Vitamin A, Vitamin K, Arsenic, Boron, Chromium, Copper, Iodine, Fe, Manganese, Molybdenum, Nickel, Silicon, Vanadium, and $Z n(Z n)$, National Academies Press (US), Washington, DC, USA, 2001, https://www.ncbi.nlm.nih.gov/books/ NBK222317/.

[23] Institute of Medicine, EBook of Dietary Reference Intakes for Vitamin A, Vitamin K, Arsenic, Boron, Chromium, Copper, Iodine, Fe, Manganese, Molybdenum, Nickel, Silicon, Vanadium, and $Z n$ (Copper), National Academies Press (US), Washington, DC, USA, 2001, https://www.ncbi.nlm.nih.gov/ books/NBK222312/.

[24] Institute of Medicine, EBook of Dietary Reference Intakes for Vitamin A, Vitamin K, Arsenic, Boron, Chromium, Copper, Iodine, Fe, Manganese, Molybdenum, Nickel, Silicon, Vanadium, and Zn (Manganese), National Academies Press (US), Washington, DC, USA, 2001, https://www.ncbi.nlm.nih.gov/ books/NBK222332/.

[25] Institute of Medicine, EBook of Dietary Reference Intakes for Calcium, $P, M g$, Vitamin D, and Fluoride (Calcium), National Academies Press (US), Washington, DC, USA, 1997, https:// www.ncbi.nlm.nih.gov/books/NBK109827/.

[26] Institute of Medicine, EBook of Dietary Reference Intakes for Calcium and Vitamin D. 2011, National Academies Press (US), Washington, DC, USAhttps://www.ncbi.nlm.nih.gov/ books/NBK56070/.

[27] Institute of Medicine, EBook of Dietary Reference Intakes for Water, $\mathrm{K}, \mathrm{Na}$, Chloride, and Sulfate (K), National Academies Press, Washington, DC, USA, 2005, https://www.ncbi.nlm. nih.gov/books/NBK545428/.

[28] Institute of Medicine, EBook of Dietary Reference Intakes for Water, $\mathrm{K}, \mathrm{Na}$, Chloride, and Sulfate, National Academies Press. Na and Chloride, Washington, DC, USA, 2005, https:// www.ncbi.nlm.nih.gov/books/NBK545428/.

[29] Institute of Medicine, EBook of Dietary Reference Intakes for Calcium, $P, M g$, Vitamin $D$, and Fluoride (P), National Academies Press (US), Washington, DC, USA, 1997, https:// www.ncbi.nlm.nih.gov/books/NBK109813/.

[30] Institute of Medicine, EBook of Dietary Reference Intakes for Calcium, P, Mg, Vitamin D, and Fluoride ( $M g$ ), National Academies Press (US), Washington, DC, USA, 1997, https:// www.ncbi.nlm.nih.gov/books/NBK109816/.

[31] Institute of Medicine, EBook of Dietary Reference Intakes for Vitamin C, Vitamin E, Se, and Carotenoids (Se), National Academies Press (US), Washington, DC, USA, 2000, https:// www.ncbi.nlm.nih.gov/books/NBK225470/.

[32] H. U. S. Clifford, Pulse Quality Survey, North State University, Fargo, ND, USA, 2018, http://www.northernpulse.com/.

[33] T. H. Hefnawy, "Effect of processing methods on nutritional composition and anti-nutritional factors in lentils (Lens culinaris)," Annals of Agricultural Sciences, vol. 56, no. 2, pp. 57-61, 2011.

[34] M. Z. U. Haq, S. Ahmad, M. A. Shad et al., "Compositional studies of lentil (Lens culinaris Medik.) cultivars commonly grown in Pakistan," Pakistan Journal of Botany, vol. 43, no. 3 , pp. 1563-1567, 2011.

[35] N. Wang, D. W. Hatcher, R. Toews, and E. J. Gawalko, "Influence of cooking and dehulling on nutritional composition of several varieties of lentils (Lens culinaris)," $L W T$ Food Science and Technology, vol. 42, no. 4, pp. 842-848, 2009.

[36] N. Wang and J. Daun, "Effects of variety and crude protein content on nutrients and anti-nutrients in lentils ()," Food Chemistry, vol. 95, no. 3, pp. 493-502, 2006.

[37] Z. Kerem, S. Lev-Yadun, A. Gopher, P. Weinberg, and S. Abbo, "Chickpea domestication in the Neolithic Levant through the nutritional perspective," Journal of Archaeological Science, vol. 34, no. 8, pp. 1289-1293, 2007.

[38] A. K. Jukanti, P. M. Gaur, C. L. L. Gowda, and R. N. Chibbar, "Nutritional quality and health benefits of chickpea (Cicer arietinum L.): a review," British Journal of Nutrition, vol. 108, no. S1, pp. S11-S26, 2012.

[39] P. T. Lieu, M. Heiskala, P. A. Peterson, and Y. Yang, "The roles of Fe in health and disease," Molecular Aspects of Medicine, vol. 22, no. 1-2, pp. 1-87, 2001.

[40] L. Maxfield and J. S. Crane, "Zn deficiency," in StatPearlsStatPearls Publishing, Treasure Island, FL, USA, 2020, https:// www.ncbi.nlm.nih.gov/books/NBK493231/.

[41] M. Aliasgharpour and M. Rahnamaye Farzami, "Trace elements in human nutrition: a review," International Journal of Medical Investigation, vol. 2, no. 3, pp. 115-128, 2013.

[42] J. C. Tan, D. L. Burns, and H. R. Jones, "Severe ataxia, myelopathy, and peripheral neuropathy due to acquired copper deficiency in a patient with history of gastrectomy," Journal of Parenteral and Enteral Nutrition, vol. 30, no. 5, pp. 446-450, 2006.

[43] L. Li and X. Yang, "The essential element manganese, oxidative stress, and metabolic diseases: links and interactions," Oxidative Medicine and Cellular Longevity, vol. 2018, Article ID 7580707, 11 pages, 2018.

[44] J. A. Beto, "The role of calcium in human aging," Clinical Nutrition Research, vol. 4, no. 1, pp. 1-8, 2015.

[45] M. Stone, L. Martyn, and C. Weaver, "Potassium intake, bioavailability, hypertension, and glucose control," Nutrients, vol. 8, no. 7, p. 444, 2016.

[46] G. K. Schwalfenberg and S. J. Genuis, "The importance of magnesium in clinical healthcare," Scientifica, vol. 2017, Article ID 4179326, 14 pages, 2017.

[47] U. Gröber, J. Schmidt, and K. Kisters, "Magnesium in prevention and therapy," Nutrients, vol. 7, no. 9, pp. 8199-8226, 2015.

[48] M. S. Razzaque, "Phosphate toxicity: new insights into an old problem," Clinical Science, vol. 120, no. 3, pp. 91-97, 2011.

[49] M. Elias, M. Laranjo, A. Cristina Agulheiro-Santos, and M. Eduarda Potes, "The role of salt on food and human health," Salt in the Earth, 2020.

[50] M. P. Rayman, "The importance of selenium to human health," The Lancet, vol. 356, no. 9225, pp. 233-241, 2000.

[51] R. A. Ghavidel and J. Prakash, "The impact of germination and dehulling on nutrients, antinutrients, in vitro iron and calcium bioavailability and in vitro starch and protein digestibility of some legume seeds," LWT-Food Science and Technology, vol. 40, no. 7, pp. 1292-1299, 2007.

[52] R. F. Hurrell, M. Reddy, and J. D. Cook, "Inhibition of nonhaem iron absorption in man by polyphenolic-containing beverages," British Journal of Nutrition, vol. 81, no. 4, pp. 289-295, 1999. 
[53] S. C. Noonan and G. P. Savage, "Oxalate content of foods and its effect on humans," Asia Pacific Journal of Clinical Nutrition, vol. 8, no. 1, pp. 64-74, 1999.

[54] R. M. Welch and R. D. Graham, "Breeding for micronutrients in staple food crops from a human nutrition perspective," Journal of Experimental Botany, vol. 55, no. 396, pp. 353-364, 2004.

[55] E. Graf and J. W. Eaton, "Antioxidant functions of phytic acid," Free Radical Biology and Medicine, vol. 8, no. 1, pp. 61-69, 1990.

[56] E. R. Morris and A. D. Hill, "Inositol phosphate content of selected dry beans, peas, and lentils, raw and cooked," Journal of Food Composition and Analysis, vol. 9, no. 1, pp. 2-12, 1996.

[57] R. F. Hurrell, "Influence of vegetable protein sources on trace element and mineral bioavailability," The Journal of Nutrition, vol. 133, no. 9, pp. 2973S-2977S, 2003.

[58] R. K. Gupta, S. S. Gangoliya, and N. K. Singh, "Reduction of phytic acid and enhancement of bioavailable micronutrients in food grains," Journal of Food Science and Technology, vol. 52, no. 2, pp. 676-684, 2013.

[59] A. Khalil and E. H. Mansour, "The effect of cooking, autoclaving and germination on the nutritional quality of faba beans," Food Chemistry, vol. 54, no. 2, pp. 177-182, 1995.

[60] R. D. Graham, R. M. Welch, and H. E. Bouis, "Addressing micronutrient malnutrition through enhancing the nutritional quality of staple foods: principles, perspectives and knowledge gaps," Advances in Agronomy, vol. 70, pp. 77-142, 2001. 